\title{
Urinary Extraction of Oxidative Damage in Carpet Weavers
}

\author{
Rashid Heidarimoghadam¹, Akram Ranjbar², Neda Mahdavi1, Tvakol Heidary Shayesteh², \\ Mohammad Faridan ${ }^{3}$, Leila Tajik ${ }^{4}$ \\ ${ }^{1}$ Department of Ergonomics, Hamadan University of Medical Sciences, Hamadan, Iran \\ ${ }^{2}$ Department of Pharmacology \& Toxicology, Hamadan University of Medical Sciences, Hamadan, Iran \\ ${ }^{3}$ Department of Occupational Hygiene, Lorestan University of Medical Sciences, Khoramabad, Iran \\ ${ }^{4}$ Department of Occupational Hygiene, Hamadan University of Medical Sciences, Hamadan, Iran \\ Email: Dr haidari@yahoo.com, a.ranjbar@umsha.ac.ir, nmahdavi1@yahoo.com, shayesteh 777@yahoo.com, \\ mfereidan@yahoo.com, ${ }^{*}$ I.tajik@umsha.ac.ir
}

Received 7 May 2014; revised 19 June 2014; accepted 6 July 2014

Copyright (C) 2014 by authors and Scientific Research Publishing Inc.

This work is licensed under the Creative Commons Attribution International License (CC BY).

http://creativecommons.org/licenses/by/4.0/

(c) (i) Open Access

\section{Abstract}

Nearly 8.5 million people in Iran directly or indirectly make a living from hand-made carpet weaving industry. Ongoing work, poor postures, breathing problems and skin irritations are among factors affecting the health, safety and wellbeing of those involved in this industry. Hence, considering such factors seem to improve the quality of carpet as a valuable cultural commodity and expand its export. Accordingly, this study investigates the oxidative stress biomarkers among involved and non-involved people in the hand-made carpet industry. 25 carpet maker and 25 ordinary people (not involved in carpet industry) who had been matched for age and sex were selected as study groups. The level of oxidative stress biomarkers such as antioxidant capacity, total thiols and catalase were measured among subjects, and finally the biomarkers were compared between the two groups. To compare the oxidative stress biomarkers in two groups, Independent Sample T Test was used. The mean levels of total antioxidant capacity showed no significant difference between the two groups ( $0.05<$ p-value). Two other markers, thiols and catalase, in both groups showed significant differences $(0.05>$ p-value $)$. In conclusion, carpet weaving industry induces oxidative stress and natural antioxidant may be considered beneficial for the protection of oxidative damage in such subjects.

\section{Keywords}

Carpet Weaver, Oxidative Stress, Antioxidant Capacity

\footnotetext{
${ }^{*}$ Corresponding author.
}

How to cite this paper: Heidarimoghadam, R., Ranjbar, A., Mahdavi, N., Shayesteh, T.H., Faridan, M. and Tajik, L. (2014) Urinary Extraction of Oxidative Damage in Carpet Weavers. Health, 6, 1680-1685. 


\section{Introduction}

Carpet hand weaving is a common practice in countries such as Iran, China, Turkey, India, Pakistan, Russia, Egypt, Nepal and Afghanistan. In Iran, hand-woven carpets are produced nearly always in home-based workshops categorized as informal small-scale industry, often organized around families and done in homes as informal small-scale industry [1].

Hand woven carpets are the most important Iranian non-oil exported goods and have an outstanding place in the country economy from the viewpoint of its share of 1\% in GNP and employment [2]. In Iran, nearly 2.2 million full time and part time weavers are working and about 8.5 million of people directly or indirectly live on hand-woven carpet industry [3]. The art of carpet weaving in Iran is becoming more industrialized but in many parts of Iran it is still done by individuals in their homes or workshops. The work is often organized around families and carried out in homes [4]. Carpet weaving has been a major source of living for the people as it does not require resource beyond basic infrastructural facilities to weave carpets i.e. a loom, wool and basic weaving tools. It has become a common industry where carpets are woven in homes, often employing women folk in rural areas [5] [6]. However, the pathophysiology of the adverse effects of weaving process is still unknown. One hypothesis could include the induction of oxidative stress by the use of bleached silk and cotton dust in vital organs [7] [8]. Occupational toxin exposures have an important role in ROS (Reactive oxygen species) induction, which leads to the aforementioned illnesses [9] [10]. ROS reactions, including lipid peroxidation, are considered to be the important factors in the pathogenesis of a variety of diseases. ROS can damage proteins, lipids, carbohydrates and nucleic acids. ROS can easily produce injuries to cell membranes by initiation of polyunsaturated fatty acid peroxidation.

To shed more light to this theory and also elucidating the status of oxidative stress biomarkers in carpet weaving, we investigated carpet weavers' antioxidant status by measuring their urine total antioxidant capacity (TAC), extent of catalase (CAT) activity and concentration of total thiol groups and compared the results with a matched control group. To our knowledge, this is the first study presenting data that carpet weavers are tolerating increased and persistent oxidative stress.

\section{Methods}

\subsection{Subjects}

The study was carried out in 25 female subjects working in carpet industry located in Iran. Control subjects, 25 ordinary people (not involved in carpet industry), were matched regarding age and socio-economic status as that of study group subjects. Demographic details, work history and habits of the subjects were collected using a questionnaire.

These subjects were active, starting at 7:30 AM and finishing at 4:00 PM. After this control period, the urine samples collected whole expectorated from each subject, into sterile tubes, between 9:00 and 10:00 AM [11]. All procedures for this investigation were approved by the Ethics committee and Vice Chancellor of Research of Hamadan University of Medical Sciences.

Frozen urine samples from study subjects were thawed and analyzed on ice immediately, then centrifuged at $3000 \mathrm{rpm}$ and the supernatant were used for analysis of: catalase (CAT), total thiol molecules (TTG) and total antioxidant capacity (TAC).

\subsection{Assay of Total Antioxidant Capacity}

Antioxidant capacity was determined by measuring the amount of reduction of $\mathrm{Fe}^{3+}$ to $\mathrm{Fe}^{2+}$ as named FRAP test. Briefly, in this test, the medium is exposed to $\mathrm{Fe}^{3+}$ and the antioxidants present in medium start to produce $\mathrm{Fe}^{2+}$ as an antioxidant activity. The reagent contained TPTZ dissolved in acetate buffer ( $\mathrm{pH} \mathrm{3.6)} \mathrm{and} \mathrm{FeCl}_{3}$. The complex between $\mathrm{Fe}^{2+}$ and TPTZ gives a blue color with absorbance at $593 \mathrm{~nm}$ that is measured on the basis of a calibration curve obtained by different concentrations of $\mathrm{FeCl}_{3}$ [12].

\subsection{Assay of CAT}

Catalase activity was determined spectrophotometrically on saliva and expressed in units per mililiter. CAT activity was assayed in samples by measuring the absorbance decrease at $240 \mathrm{~nm}$ in a reaction medium containing 
$10 \mathrm{mM} \mathrm{H}_{2} \mathrm{O}_{2}$, and $50 \mathrm{mM}$ sodium phosphate buffer ( $\mathrm{pH}$ 7.0). One unit of the enzyme is defined as $1 \mathrm{M} \mathrm{H}_{2} \mathrm{O}_{2}$ consumed/min, and the specific activity is reported as units/ml saliva [13].

\subsection{Assay of Total Thiol Molecules (TTG)}

Total thiol content was determined in plasma by the method of Hu (24). A volume of plasma $(0.20 \mathrm{ml})$ was mixed in a $10 \mathrm{ml}$ test tube with $0.6 \mathrm{ml}$ of Tris-EDTA buffer (Tris base $0.25 \mathrm{M}$, EDTA $20 \mathrm{mM}$, pH 8.2) followed by the addition of $40 \mathrm{ml}$ of $10 \mathrm{mM}$ of DTNB in methanol. The final volume of the reaction mixture was made up to $4.0 \mathrm{ml}$ by adding $3.16 \mathrm{ml}$ of methanol. The test tube was capped, and the color was developed for 15 - 20 min, followed by centrifugation at $3000 \mathrm{~g}$ for $10 \mathrm{~min}$ at ambient temperature. The absorbance of the supernatant was measured at $412 \mathrm{~nm}$ [14].

\subsection{Statistical Analysis}

Results are expressed as Mean \pm SE, 95\% CI. The differences between groups were assessed by Student's $t$-test. A probability of 0.05 was assumed to specify a significant difference.

\section{Results}

As shown in Table 1, the means of age for carpet weavers and control groups were $31.24 \pm 7.24$ and $30.58 \pm 4.3$ respectively. They also had $5.2 \pm 6.26$ years of work experience. Carpet weavers and control groups were not significantly different in terms of age.

Biomarkers of oxidative stress including, antioxidant capacity, total amount of thiols and catalase activity (CAT) were measured in both groups. The results are as follows:

As shown in Table 2, the means of antioxidant capacity, thiols and catalase activity (CAT) among the carpet weavers are respectively $690.16 \pm 331.23,0.041 \pm 0.034$ and $1.453 \pm 1.136$, which if compared with the control group, demonstrate a reduction in thiol and antioxidant capacity. The catalase mean, however, has increased.

The comparison of oxidative stress biomarkers between two groups are presented in Figures 1-3.

Comparing the means of carpet weavers' urine antioxidant total capacity with the control group indicate that the latter has reduced, in a way that the means of carpet weavers' urine antioxidant capacity are less than controls.

Thiol groups are also the other markers of the injury induced by the free radicals. Such groups which are usually sensitive to oxidative damage, will result in minimizing the injuries. For this reason the means of carpet weavers' thiols groups show a significant decrease compared to the controls.

The means of CAT activity in both groups of carpet weavers and the controls indicated that there is an increased activity of this enzyme among the carpet weavers. Found in most organs of the body, this enzyme is in charge of break down the hydrogen peroxide into oxygen and water.

Comparison of the oxidative stress biomarkers in the two groups by the use of Independent sample $\mathrm{T}$ test showed that the p values for thiol, CAT and total antioxidant capacity group were $0.003,0.036$ and 0.815 respectively.

Table 1 . The means of age for carpet weavers and control groups.

\begin{tabular}{ccc}
\hline Variable & Carpet weavers & Control groups \\
\hline Age (year) & $17-45$ & $20-45$ \\
$\mu \pm \mathrm{SD}$ & $31.24 \pm 7.24$ & $30.58 \pm 4.3$ \\
\hline
\end{tabular}

Table 2. Mean standard deviation and confidence level of oxidative stress biomarkers in two groups.

\begin{tabular}{ccc}
\hline Variable & Carpet weavers $(\mu \pm$ SD $)$ & Control groups $(\mu \pm$ SD $)$ \\
\hline FRAP & $690.16 \pm 331.23$ & $712.72 \pm 346.81$ \\
Thiol & $0.041 \pm 0.034$ & $0.095 \pm 0.077$ \\
CAT & $1.453 \pm 1.136$ & $0.876 \pm 0.705$ \\
\hline
\end{tabular}




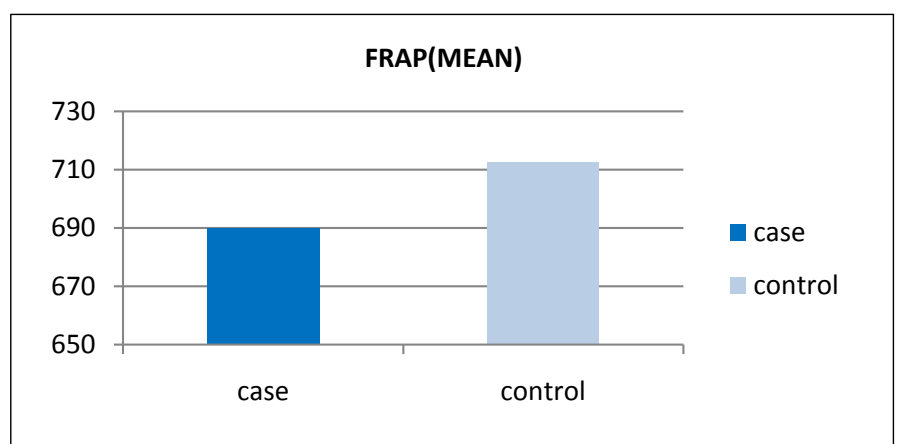

Figure 1. Plot of TAC in carpet weavers and control group.

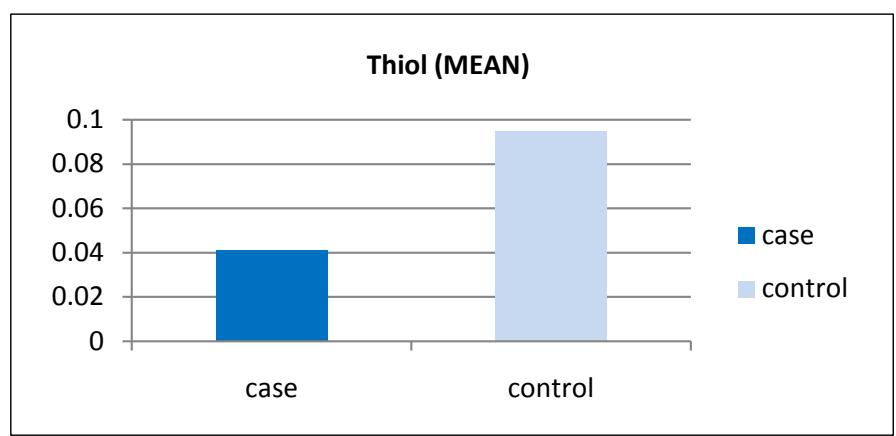

Figure 2. Plot of TTG in carpet weavers and control group.

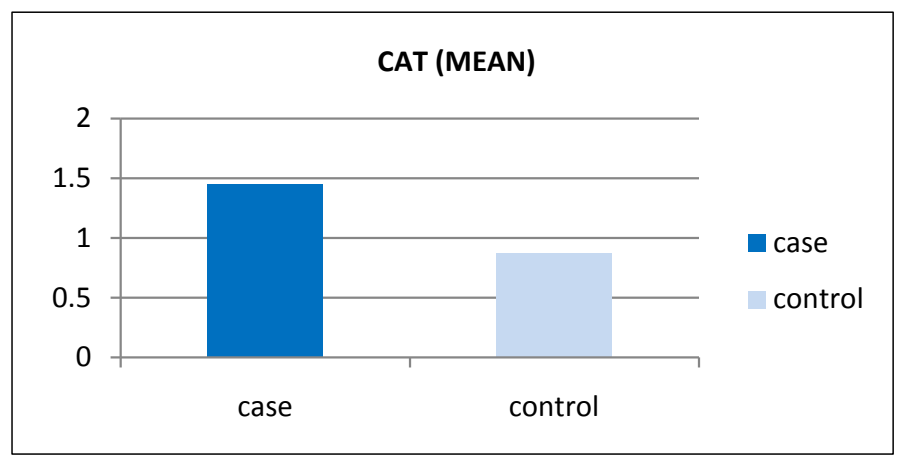

Figure 3. Plot of CAT activity in carpet weavers and control group.

\section{Discussion}

The study assessed the status of urine TAC, TTG and CAT enzyme activity in subjects exposed to carpet weaving. The results of this study partly indicated the induced oxidative damage among carpet weavers had taken place. The results showed that the rate of protein oxidation, represented in thiol groups, and also catalase activity was significantly lower in these subjects if compared to the controls. Another biomarker, antioxidant capacity, has also shown some alterations, which were not statistically significant.

In the similar works, previous studies have shown that chemical laboratory, aluminum industry and pesticides workers personnel had been induced oxidative stress [15]-[17].

Carpet weaving is an extensively tedious profession, requiring long hours of static work and can then be categorized as a high-risk occupation [5]. In a study on carpet mending operation as a part of carpet industry, the researchers found that the working conditions were poor and awkward working postures were very common [18]. Cough, sputum production and breathlessness are some of the reported respiratory symptoms in workers, while occupational asthma and hypersensitivity pneumonitis are recognized clinical syndromes common in such workers [19] the overall effect of which is a lower level of lung function in these workers. The previous study 
showed that $63 \%$ of the women had respiratory problems such as asthma due to cotton dust, or respiratory irritation due to inhalation of chemicals used to bleach silk and cotton [20]. The use of chemical dyes to colour the silk and cotton caused some women to develop allergic skin rashes. The investigators reported that work-aggravated asthma is caused by mechanical irritation of the airways from non allergenic dust and by chemical irritation. Most inhaled dust is filtered out by the upper airways or cleared by the ciliated epithelium of large airways. If these defenses are overwhelmed by the fine dust, the lung reacts with an alveolar and interstitial inflammation that may leave adverse effects on respiratory system [21].

The study demonstrated that the continual exposure to dust in weavers in this industry is associated with significantly lower pulmonary function, higher prevalence of respiratory symptoms, and weavers show signs of airway obstruction compared to workers not exposed to this type of dust [22]. The scientist assessed the adverse influence of carpet weaving on lung functions and the nutritional status of children employed in carpet weaving factories [23].

The sulphydryl group (SH) of glutathione confers its protective action against oxidative damage. Glutathione exists in two forms: the reduced form (GSH) and the oxidized form (GSSG). The protective action of glutathione against reactive oxygen species (ROS) is facilitated by the interactions with its associated enzymes, such as glutathione peroxidase and glutathione reductase. Glutathione (GSH), a tripeptide thiol ( $\gamma$-glutamylcysteinylglycine), is the major non-protein sulphydryl compound in mammalian cells that is known to have numerous biological functions. This thiol plays a prominent role in detoxification and antioxidation of exogenous and endogenous compounds, as well as maintaining the intracellular redox status. Glutathione is a natural reservoir of reducing power, which can be quickly used by the cells as a defense against oxidative stress [24].

Despite taking all the measures to properly achieve the objectives of the present study, the researchers encountered several limitations and shortcomings among which was the difficulty in taking the urine samples of the carpet weavers due to the scattered pattern of their workplace locations in the city and lack of communal carpet weaving workshops (as it is common in the other parts of Iran).

\section{Conclusions and Recommendation}

Overall in this study the evaluation of the biomarkers of oxidative stress showed that the carpet weavers are to some extent prone to develop oxidative injury.

Further studies are warranted to determine pollutions specific in workplace and effects of various natural antioxidants can be recommended as a dietary strategy to lower the risk of oxidative injuries in these subjects.

\section{Acknowledgements}

The authors would like to thank Hamadan University of Medical Sciences for financial support of this research.

\section{References}

[1] Choobineh, A., Hosseini, M., Lahmi, M., Khani Jazani, R. and Shahnavaz, H. (2007) Musculoskeletal Problems in Iranian Hand-Woven Carpet Industry: Guidelines for Workstation Design. Applied Ergonomics, 38, 617-624. http://dx.doi.org/10.1016/j.apergo.2006.06.005

[2] Mahdavi, H. (2000) What Should Be Done for Iranian Carpet Export. Kayhan, 16940-16945.

[3] Sobhe, K. (1997) A Research in International Market of Iranian Carpet and Its Export Development. Iran Hand-Woven Carpet Magazine, 10, 31-46.

[4] Wani, K.A. and Jaiswal, Y. (2011) Occupational Health Risk Factors in Carpet Industry: A Review. Asian Journal of Experimental Biological Sciences, 2, 135-139.

[5] Choobineh, A., Shahnavaz, H. and Lahmi, M. (2004) Major Health Risk Factors in Iranian Hand-Woven Carpet Industry. International Journal of Occupational Safety and Ergonomics, 10, 65-78.

[6] Budak, F., Yenigun, N., Özbek, A., Orhan, S. and Komsuoglu, S. (2001) Carpal Tunnel Syndrome in Carpet Weavers. Electromyography and Clinical Neurophysiology, 41, 29-32.

[7] Malekirad, A.A., Ranjbar, A., Rahzani, K., Kadkhodaee, M., Rezaie, A., Taghavi, B., et al. (2005) Oxidative Stress in Operating Room Personnel: Occupational Exposure to Anesthetic Gases. Human \& Experimental Toxicology, 24, 597601. http://dx.doi.org/10.1191/0960327105ht565oa

[8] Allaouchiche, B., Debon, R., Goudable, J., Chassard, D. and Duflo, F. (2001) Oxidative Stress Status during Exposure to Propofol, Sevoflurane and Desflurane. Anesthesia \& Analgesia, 93, 981-985. 
http://dx.doi.org/10.1097/00000539-200110000-00036

[9] Sugamura, K. and Keaney Jr., J.F. (2011) Reactive Oxygen Species in Cardiovascular Disease. Free Radical Biology and Medicine, 51, 978-992. http://dx.doi.org/10.1016/j.freeradbiomed.2011.05.004

[10] Halliwell, B. (1991) Reactive Oxygen Species in Living Systems: Source, Biochemistry, and Role in Human Disease. The American Journal of Medicine, 91, S14-S22. http://dx.doi.org/10.1016/0002-9343(91)90279-7

[11] Muniz, J.F., McCauley, L., Scherer, J., Lasarev, M., Koshy, M., Kow, Y., et al. (2008) Biomarkers of Oxidative Stress and DNA Damage in Agricultural Workers: A Pilot Study. Toxicology and Applied Pharmacology, 227, 97-107. http://dx.doi.org/10.1016/j.taap.2007.10.027

[12] Benzie, I.F.F. and Strain, J. (1996) The Ferric Reducing Ability of Plasma (FRAP) as a Measure of “Antioxidant Power”: The FRAP Assay. Analytical Biochemistry, 239, 70-76. http://dx.doi.org/10.1006/abio.1996.0292

[13] Sinha, A.K. (1972) Colorimetric Assay of Catalase. Analytical Biochemistry, 47, 389-394. http://dx.doi.org/10.1016/0003-2697(72)90132-7

[14] Hu, M. and Dillard, C. (1994) Plasma SH and GSH Measurement. Methods in Enzymology, 233, 87.

[15] Tavakol, H.S., Akram, R., Azam, S. and Nahid, Z. (2013) Protective Effects of Green Tea on Antioxidative Biomarkers in Chemical Laboratory Workers. Toxicology and Industrial Health. http://dx.doi.org/10.1177/0748233713484659

[16] Ranjbar, A., Pasalar, P. and Abdollahi, M. (2002) Induction of Oxidative Stress and Acetylcholinesterase Inhibition in Organophosphorous Pesticide Manufacturing Workers. Human \& Experimental Toxicology, 21, 179-182. http://dx.doi.org/10.1191/0960327102ht2380a

[17] Ranjbar, A., Khani-Jazani, R., Sedighi, A., Jalali-Mashayekhi, F., Ghazi-Khansari, M. and Abdollahi, M. (2008) Alteration of Body Total Antioxidant Capacity and Thiol Molecules in Human Chronic Exposure to Aluminum. Toxicological \& Environmental Chemistry, 90, 707-713. http://dx.doi.org/10.1080/02772240701660650

[18] Choobineh, A., Tosian, R., Alhamdi, Z. and Davarzanie, M. (2004) Ergonomic Intervention in Carpet Mending Operation. Applied Ergonomics, 35, 493-496. http://dx.doi.org/10.1016/j.apergo.2004.01.008

[19] Rastogi, S., Ahmad, I., Pangtey, B. and Mathur, N. (2003) Effects of Occupational Exposure on Respiratory System in Carpet Workers. Indian Journal of Occupational and Environmental Medicine, 7, 19.

[20] Nilvarangkul, K., Wongprom, J., Tumnong, C., Supornpun, A., Surit, P. and Srithongchai, N. (2006) Strengthening the Self-Care of Women Working in the Informal Sector: Local Fabric Weaving in Khon Kaen, Thailand (Phase I). Industrial Health, 44, 101-107. http://dx.doi.org/10.2486/indhealth.44.101

[21] Beckett, W.S. (2000) Occupational Respiratory Diseases. New England Journal of Medicine, 342, 406-413. http://dx.doi.org/10.1056/NEJM200002103420607

[22] Shamssain, M. and Shamsian, N. (1997) Respiratory Symptoms and Pulmonary Function in a Group of Women Weavers in South Africa. Annals of Human Biology, 24, 299-306. http://dx.doi.org/10.1080/03014469700005042

[23] Joshi, S., Sharma, U., Sharma, P., Pathak, S., Sitaraman, S. and Verma, C. (1994) Health Status of Carpet Weaving Children. Indian Pediatrics, 31, 571-575.

[24] Luberda, Z. (2005) The Role of Glutathione in Mammalian Gametes. Reproductive Biology, 5, 5-17. 
Scientific Research Publishing (SCIRP) is one of the largest Open Access journal publishers. It is currently publishing more than 200 open access, online, peer-reviewed journals covering a wide range of academic disciplines. SCIRP serves the worldwide academic communities and contributes to the progress and application of science with its publication.

Other selected journals from SCIRP are listed as below. Submit your manuscript to us via either submit@scirp.org or Online Submission Portal.
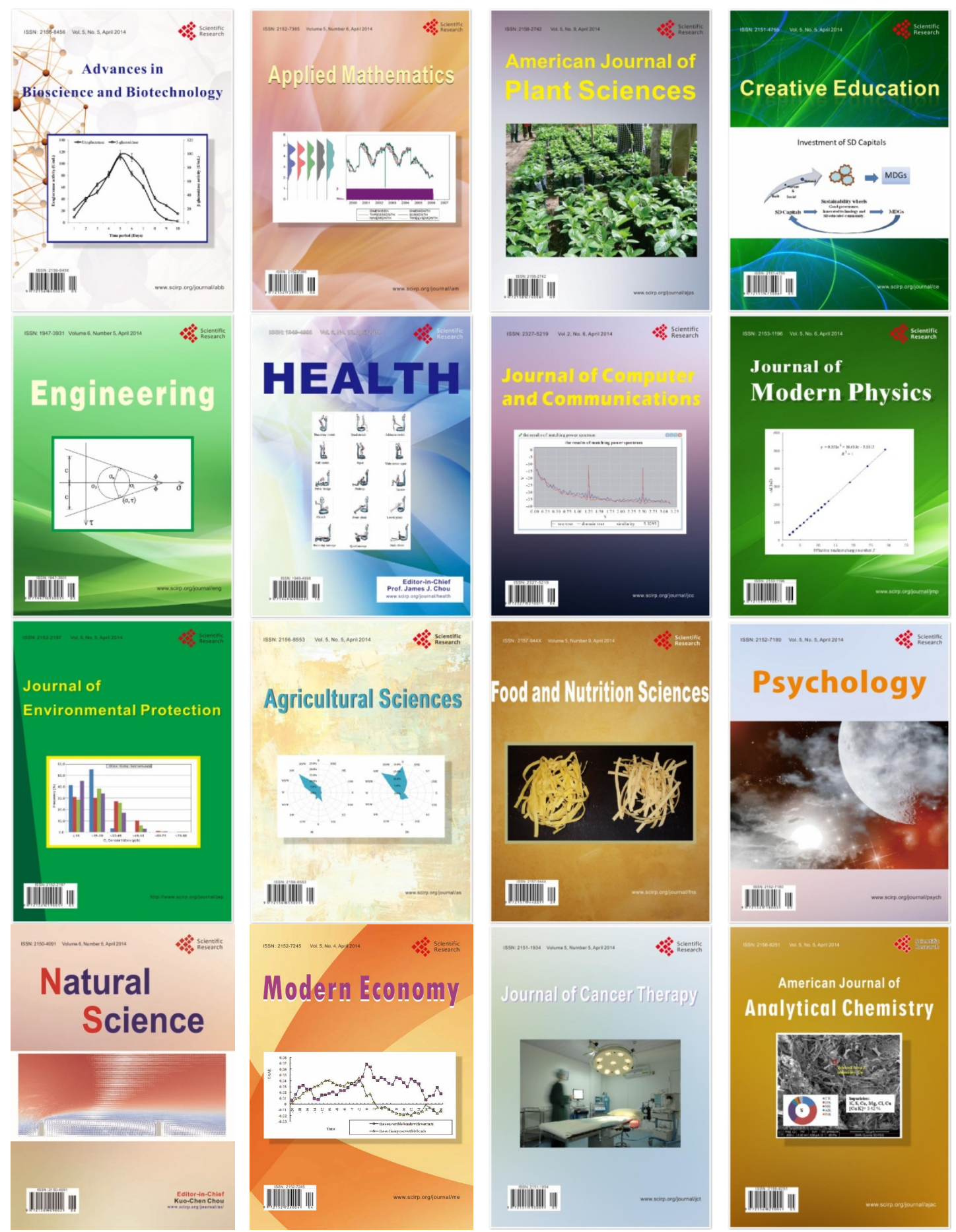